\title{
下肢の荷重配分が反復起立動作時の酸素摂取量, 心拍数に与える影響
}

\section{Effects of Differences in Body Weight Distribution in Sit-to-Stand on Oxygen Consumption and Heart Rate}

\section{上杉＼cjkstart睦1）＼cjkstart秋山 純和2)}

Mutsumi UESUGI, RPT ${ }^{1)}$, SUMIKAZU AKIYAMA, RPT, PhD²)

1) Postgraduate of Physical Therapy, Faculty of Health Science, Graduate School of the International University of Health and Welfare: 2600-1 Kitakanemaru, Otawara city, Tochigi 324-8501, Japan. TEL +81-287-24-3000

2) Teacher of Physical Therapy, Faculty of Health Science, Graduate School of the International University of Health and Welfare

Rigakuryoho Kagaku 20(2): 139-142, 2005. Submitted Dec. 8, 2004. Accepted Feb. 7, 2005.

ABSTRACT: The purpose of this study was to examine the effect of differences in weight distribution on work intensity of sit-to-stand performance. Twelve healthy adults (12 male, average age: $22.7 \pm 1.3$ ) performed a three-minute sit-to-stand task with weight bearing on one side at three target levels (50,60, and 70\% of body weight) and their oxygen consumption and heart rate were measured. Metabolic energy cost was increased with increment of difference in body weight distribution between the left and right foot. We suggest that asymmetrical body weight distribution adversely effects sit-to-stand performance.

Key words: sit-to-stand, Body Weight Distribution, work intensity

要旨: 左右下肢の荷重量における不均等は, 反復起立動作の運動強度に影響を与えると考えられる。本研究では, 下 肢荷重量の配分の違いが反復起立動作の運動強度に及ぼす影響を検討した。対象は健常成人男性12名（平均年齢22.7 歳)。測定課題は重心動摇計を用いて下肢荷重量をモニタで確認し，一側下肢の荷重量を体重の50\%，60\%，70\%に調 節して反復起立動作を行った.設定荷重量の増加に伴い，酸素摂取量，心拍数で有意な増加を認めた。荷重量の左右不 均等は，起立動作の不安定性を増大させ，運動時の運動強度を増加させると考えられる。 キーワード：反復起立動作，荷重配分，運動負荷

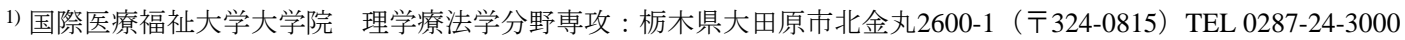
2) 国際医療福祉大学 保健学部理学療法学科

受付日 2004年12月8日＼cjkstart受理日２005年2月7日




\section{I.はじめに}

起立動作は多くの日常生活に関連した動作である。反 復起立動作はトレッドミル，エルゴメータに比較し麻痺 が重度の片麻痺患者においても施行可能な動作であり, 筋力強化，バランスの改善を目的に広く推奨される。ま た，反復起立動作を機能テストや運動負荷試験の負荷方 法に用いた報告が多くある1-3)。起立動作は神経，筋等の 疾患により障害され，脳血管障害片麻痺患者では一側下 肢の麻痺症状により, 非麻痺側へ荷重が大きくかかった 起立動作が行なわれる4)。また，大腿骨頚部骨折患者，下 腿骨折などにより一側下肢に障害が生じた場合，理学療 法場面において，一側下肢への荷重量を免荷した起立動 作，歩行動作が行なわれる。一側下肢の障害により起立 動作の荷重量は左右不均等になる。本研究では一側下肢 荷重量の違いによる運動効率, および運動負荷の変化を 検討するため, 一側下肢への荷重量を設定した反復起立 動作を行い, 設定荷重量の増加に伴った心拍数, 血圧, 酸素摂取量の変化を検討した。

\section{II. 対象と方法}

1. 対象

対象は健常成人男性 12 名, 年齢は平均 $22.7 \pm 1.3$ (歳), 身長は平均174.5 $56.8(\mathrm{~cm})$, 体重平均77.5 $2.8(\mathrm{~kg})$ で あった。

\section{2. 方法}

各被験者に対して1分間の反復起立運動を測定し, 重心 加速度を含めた両側下肢荷重量の平均值を算出し $100 \%$ とした。求められた $100 \%$ の值より $50 \%, 60 \%, 70 \%$ の值 を算出した。得られた $50 \% ， 60 \% ， 70 \%$ の值を目標荷重 量として設定し，起立動作中に左下肢の荷重量を目標荷 重量に合わせながら反復起立運動を行った。反復起立動 時の荷重量の確認には, 重心動摇計をパーソナルコン ピュータに接続し，モニタを用いて左下肢荷重量をモニ タリングした。座面の高さは腓骨頭の高さに設定にし, 股関節，膝関節は屈曲90～100度にし，両足部の位置は平 行に設定した。被験者は呼気ガス分析装置, 自動血圧を 取り付けた。測定課題は安静座位3分間を計測し，その 後, 反復起立動作3分間を計測した。測定機器は呼気ガス 分析装置（COSMED社，K4b $\mathrm{b}_{2}$ )，重心動摇計（酒井医療 株式会社, アクティブバランサー), 自動血圧計を用い, 酸素摂取量 $\left(\right.$ 以下 $\left.\mathrm{VO}_{2}\right)$ ，血圧 (以下 $\left.\mathrm{BP}\right)$ ，心拍数（以下 $\mathrm{HR})$ を計測した。 $\mathrm{VO}_{2}$ は一呼吸毎に呼気ガス分析装置を用
いて計測し，30秒間隔の平均值を求めた。BP，HRは30秒 ごとに計測した。また, 反復起立動作時のHRを安静時の HRで除して\%心拍数（以下\%HR）を算出した。設定荷重 量の3条件の測定は日を改め48時間以降1週間未満の条件 で計測した。起立速度は動作施行中，メトロノームを用 いて座位から立位，立位から座位を3秒間で一定になるよ うに行った（20回/分）。また，反復起立動作中の安定し た3回の起立動作において重心動摇計を用い, 左右下肢の 荷重量と両下肢の支持基底面内の足圧中心を計測した。 荷重量では起立動作時の最大荷重量を体重で除した值を 求めた。統計的検討は設定荷重量の要因からみた一元配 置分散分析を行い有意水準は危険率5\%未満とした。多重 比較検定にはFisher'sPLSDによるpost-hoc検定を用い，有 意水準は5\%未満とした。

\section{III. 結 果}

反復起立動作における一側下肢の荷重量の増加に伴 い, $\mathrm{VO}_{2}$ おびHRは増加した (図1, 表1)。於 2 では運動開 始後 2 分 30 秒時と 3 分時において各荷重条件で主効果を認 めた（2分30秒時: $\mathrm{F}_{2.33}=5.40 .3$ 分 : $\left.\mathrm{F}_{2.33}=5.00, \mathrm{p}<0.05\right) 。$ 多重比較検定では，各設定荷重量50\%と70\%の間に有意 差を認めた。設定荷重量50\%では運動開始後の全測定時 期において最も低い值を示し, 設定荷重量の増加に伴い 酸素摂取量の増加が大きかった。HRでは運動開始後1分 30 秒時で主効果を認めた $\left(F_{2.33}=3.77, \mathrm{p}<0.05\right)$, 多重比較 検定では設定荷重量 $50 \%$ と70\%の間に有意差を認めた。 \%HRでは，運動開始後1分時と1分30秒時で各設定荷重量 間に主効果を認め (1 分時: $F_{2.33}=3.25 .1$ 分 30 秒時: $\left.\mathrm{F}_{2.33}=3.28, \mathrm{p}<0.05\right), 1$ 分時では50\%と70\%, 1分30秒時で は $50 \%$ と 70\%，60\%と70\%の間に有意差を認めた。尚， $\mathrm{BP}$ 変化では，収縮期血圧，拡張期血圧共に片脚下肢の

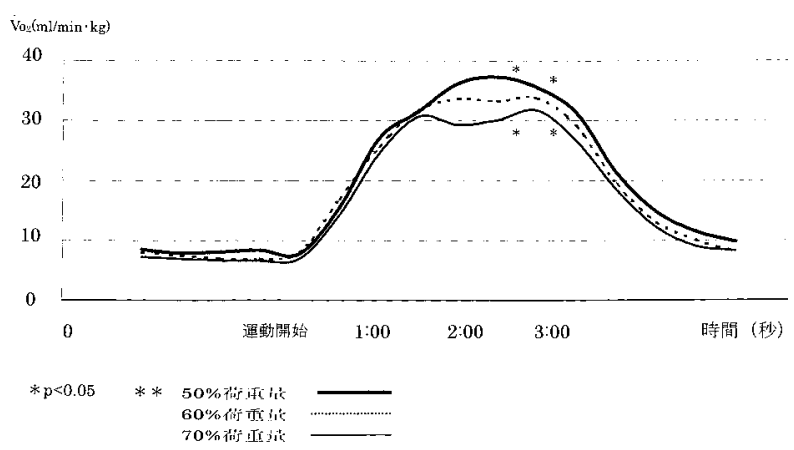

図1 下肢の各荷重条件での反復起立運動における酸素摂取 量の経時的変化 
表1 下肢の各荷重条件での反復起立運動における心拍数および\%心拍数の経時的変化

\begin{tabular}{|c|c|c|c|c|c|c|}
\hline & 安静時 & 1 分 & 1 分 30 秒 & 2 分 & 2 分 30 秒 & 3 分 \\
\hline \multicolumn{7}{|l|}{ 心拍数（HR） } \\
\hline 下肢荷重量 50\% & $80.6 \pm 13.3$ & $97.4 \pm 11.0$ & $111.0 \pm 11.27$ & $118.1 \pm 14.4$ & $121.3 \pm 11.0$ & $125.1 \pm 10.7$ \\
\hline 下肢荷重量 60\% & $80.4 \pm 13.0$ & $94.6 \pm 18.1$ & $112.0 \pm 14.2$ & $116.4 \pm 11.2$ & $122.5 \pm 13.6$ & $125.2 \pm 13.0$ \\
\hline 下肢荷重量 70\% & $85.0 \pm 14.0$ & $109.7 \pm 16.5$ & $121.0 \pm 16.2\rfloor$ & $122.6 \pm 11.8$ & $131.0 \pm 8.8$ & $133.8 \pm 11.9$ \\
\hline \multicolumn{7}{|l|}{ \%心拍数（\%HR） } \\
\hline 下肢荷重量 50\% & & $100.6 \pm 11.42 \neg$ & $116.0 \pm 8.9$ & $132.8 \pm 13.1$ & $141.8 \pm 14.3$ & $145.7 \pm 13.8$ \\
\hline 下肢荷重量 60\% & & $99.0 \pm 14.05$ & $113.3 \pm 14.0_{\neg}$ & $134.5 \pm 13.6$ & $139.8 \pm 15.0$ & $147.0 \pm 15.9$ \\
\hline 下肢荷重量 70\% & & $110.5 \pm 20.9 \square$ & $131.2 \pm 31.9]$ & $145.4 \pm 16.0$ & $147.5 \pm 18.6$ & $157.6 \pm 17.7$ \\
\hline
\end{tabular}

荷重量の変化による有意差は認めなかった。

荷重量の結果では設定荷重量の増加に伴い実測荷重量 は増加し主効果を認めた $\left(\mathrm{F}_{2.33}=48.08, \mathrm{p}<0.05\right)$ 。実測荷 重量の值は，設定荷重量50\%で左右下肢それぞれ51.7士 $0.04 / 54.4 \pm 0.03 ， 60 \%$ で $61.3 \pm 0.04 / 43.5 \pm 0.09 ， 70 \%$ で $71.0 \pm 0.08 / 37.7 \pm 0.10 （ \%)$ であった。足圧中心の結果 では, 設定荷重量の増加に伴い左右方向の最大振幅は増 加し，主効果を認めた（F2.33=9.40, p <0.05）。多重比較 検定では，各設定荷重量間に有意差を認めた（表2）。

\section{IV. 考 察}

起立動作時の実測荷重量の結果より，各設定荷重量に おける荷重測下肢の平均值は設定荷重量と一致した結果 であり, 起立動作時における荷重量の調節方法は妥当で あったと考えられる。反復起立動作時の酸素摂取量の変 化では，一側下肢の荷重量増加に伴い $\mathrm{VO}_{2}$ が増加を認め, 3つの設定荷重量において運動開始後2分30秒から3分で 定常状態が観察された。HRの結果においても一側下肢の 荷重量の増加に伴い高い值を示した。これらの $\dot{\mathrm{VO}}_{2}, \mathrm{HR}$ の結果から一側下肢の荷重量増加に伴った反復起立動作 時のエネルギー消費の増大, 運動強度の増加が認められ た。

反復起立動作において一側下肢の荷重量増加に伴った 運動強度の増加の要因として, 下肢の筋活動の変化によ る影響が考えられる。起立動作において，殿部の離床か ら立位までの期は股関節, 膝関節の伸展動作によって特 徵付けられる。この期では起立動作時における荷重量の 垂直成分において最大となり，股関節，膝関節における トルクの増大が生じ，膝関節や股関節の伸展筋群におい て最大の筇活動が生じる5)。本研究における荷重量の調節
表2 各荷重条件における起立動作時の足圧中心最大振幅 距離

(単位 : $\mathrm{cm}$ )

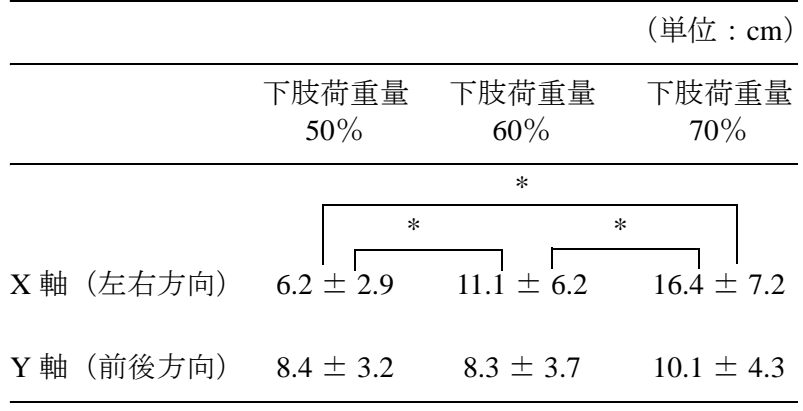

方法は起立動作中の荷重最大值を目標荷重量として設定 したため，膝関節，股関節伸展動作がおこる時点での筋 活動が大きく影響したと考えられる。下肢荷重量の結果 では設定荷重量の増加に伴った実測荷重量の増加を認め たことより，一側下肢の荷重量増加に伴い起立動作時に おける下肢の最大筋活動に変化が生じたことが推測され る。起立動作では一側下肢の荷重量増加により荷重側下 肢の前脛骨筋, 大腿四頭筋の筋活動増大が生じるとされ 6,7), 反復起立動作において一側下肢の荷重が増加した場 合では，荷重側下肢の筋活動が増加した起立動作の繰り 返しであると考えられる。

筋活動に対寸る生理的反応は運動の種類, 負荷強度の 程度によって異なり, 運動に参与する筋量と生理的反応 の関係は一様ではないとされる8)。例えば，等尺性収縮で は同じ負荷であっても活動する筋量が多い方が生理的反 忘は高くなり，等張性運動では筋量が少ない場合で高い 生理的反応を示す。久家らの報告では, 自転車エルゴメー タで一側下肢による駆動と両側下肢による駆動を比較 し, 一側下肢で駆動を行った場合で酸素摂取量, 心拍数 
の生理的反応が高かった ${ }^{9)}$ 。側下肢の駆動において高い 生理的反応が生じる理由として, 筋量が少ない筋活動で 交感神経の刺激が増すこと，また，一側下肢の活動では 無酸素性作業閾值が低いこと，下肢の血量が多くなり末 梢血管抵抗が著明に低いことをあげている9)。起立動作の 下肢筋活動は等張性運動であるといえる。つまり，一側 下肢の筋活動が増大した等張性運動であったことが考え られる。そのため，一側下肢の荷重増加では，両側下肢 の活動に比較し運動に参与する筋量が少ないため, 反復 起立動作時の生理的反応が高くなったと考えられる。

足圧中心の変化では一側下肢への荷重量の増大に伴い 左右方向の動摇が有意に増大した。身体重心を側方に移 動する動作では身体重心の移動は足圧中心の変化と相互 関連的な変化を示し，足圧中心の変化は身体重心の動摇 に関連する10)。起立動作における一側下肢の荷重量増加 に伴った足圧中心の側方動摇の増大は身体重心の動摇の 増大を反映している。このため, 一側下肢の荷重量の増 加により身体重心の左右方向の動摇が増大し, 起立動作 はより不安定になったことが考えられる。さらに，動作 時の不安定性の増大は安定制御のため体幹, 下肢におい て異なった筋活動の増大, 活動筋の増加が生じることが 考えられる11)。これらの要因より，一側下肢の荷重量の 違う起立動作では異なった起立動作パターンで遂行され るといえる。運動パターンが異なる同一動作ではその運 動の過程が異なるため, 物理的負荷量は必ずしも同じで はない12)ことより，異なった起立動作パターンでは動作 時の物理的運動強度に相違が生じ, 運動効率が変化した と考えられる。

本研究の結果より, 下肢荷重量が両側均等な起立動作 が最も効率が良く, 一側下肢への荷重量の増加に伴い, 起立動作の運動効率が低下寸ることがわかった。これよ り, 起立動作は片脚のみの活動では非効率的であり, 両 側下肢の協調した活動が安定した起立動作には重要であ ることが言える。また，一側の下肢の障害は非効率的な 起立動作になり, 反復起立動作では高い運動強度になる
可能性が示唆された。反復起立動作は機能テストや運動 負荷試験の負荷方法に用いられるが，左右下肢の不均等 な荷重は, 反復起立動作時の生理的反応に影響を与える ため,リスク管理の観点からも重要である。

\section{引用文献}

1) Potempa K: Physiological outcomes of aerobic exercise training in hemiparetic stroke patients. Stroke, 1995, 26: 101-105.

2) 木檜 晃 : 片麻痺患者の全身持久力について（第三報）「立 ち上がり動作」負荷漸増法による健常者との比較. 医療体 育, 1998, 17(1): 25-28.

3) 大隈秀信 : 脳卒中片麻痺患者に対する AT 決定のための運動 負荷方法としての反復起立動作の検討. リハビリテーション 医学, 1994, 31(3): 165-171.

4) Cheng P-T, Liaw M-Y, Wong M-K, et al.: The sit-to-stand movement in stroke patients and its correlation with falling. Arch Phys Med Rehabil, 1998, 79: 1043-1046.

5) Janssen WGM, Bussman HBJ, Stam HJ: Determinants of the sitto-stand movement: A review. Physical Therapy, 2002, 83: 866879.

6) Kawagoe S, Tajima N, Chosa E: Biomechanical analysis of effects of foot placement with varing chair height on the motion of stand up. J Orthop Sci, 2000, 5(2): 124-133.

7) Brunt D, Greenberg BB, Wankaida S, et al.: The effect of foot placement on sit to stand in healthy young subject and patient and patients with hemiplegia. Arch Phys Med Rehabil, 2002, 83: 83924-83929.

8) 丸山仁司: 負荷方法の相違いによる生理的反応 同一負荷量 による当尺性運動. 運動生理, 1988, 3(4): 239-242.

9) 久家直巳 : 一側下肢と両側下肢による自転車エルゴメータ駆 動時の酸素摂取量と心拍数について．運動生理，1988, 3(1): 7-10.

10) 米田稔彦 : 姿勢 - 動作分析 理学療法評価学 第1版. 医学書 院，東京，2001, pp194-207.

11) 奈良 勲, 内山 靖, 内野善生・他 : 姿勢調節障害の理学療 法. 医歯薬出版, 東京, 2004, pp171-182.

12) 丸山仁司：運動発達過程における動作出現順序と酸素消費 量. 埼玉医科大学雑誌, 1988, 15(2) : 97-109. 